\title{
Symbols and Functions of Masks and Ritual Mummery of the Mordovians
}

\section{Elena Frolova}

\author{
PhD in History, Associate Professor, Kazan (Volga region) Federal University \\ elenaieup@mail.ru
}

\section{Galina Kornishina}

PhD, Doctor in History, Full Professor, Ogarev Mordovia State University

G.Kornihina@mail.ru

\section{Nadejda Belyaeva}

PhD, Doctor in History, Full Professor, Mordovia State Pedagogical Institute named after M.E. Evseev G.Kornihina@mail.ru

\section{Doi:10.5901/mjss.2015.v6n6s5p286}

\begin{abstract}
The topic relevance is based on a theoretical analysis of data associated with ritual culture of the Mordovian people, structural and functional analysis of its components, identification of their formation and development regularities and their interaction with each other. The purpose of this article is to describe the role and importance of masks and mummery in traditional rites of Moksha and Erzya, to identify general and specific characteristics of these constituent elements in rites of the Mordovians and other peoples of the Volga region. The main method used in the study is a comparative method, supplemented by ethnographic methods, such as direct observation and interviews. The article describes one of the elements of the traditional rites of the Mordvinians' mummery. There were different techniques practiced in the rites of Moksha and Erzya: they used masks, costumes, household objects. Putting a mask or a costume on, a person transformed into his character - an animal or any other creature of the beyond. In this regard, the person changed his behavior; he often went beyond the accepted norms. Later the custom of mummery lost its magical sense and became a way of entertainment, especially for young people and children.
\end{abstract}

Keywords: traditional rites, masks, mummers, totemism, travestizm.

\section{Introduction}

\subsection{Significance of the problem}

Any traditional ceremonies and rites can be characterized by multifunctionality and complex structure. Their compound components are magic actions, various meals, games, ceremonial folklore, etc. One of the components of traditional rites of the Mordovians which considered in this article is mummery. It was an element of many ceremonial cycles. For example, in during Christmas and New Year's holidays mummers carried out functions of public controllers. Visiting houses they demanded from house owners to show what they had done during the winter. The owners and their sons were to make bast shoes, arches, etc. and women and girls were to prepare yarn. If the mummers considered that the owners worked enough they sang praises. Otherwise, they sang the dishonoring songs called "paryavtnimat", and adult girls were dragged in snow as a punishment for their laziness.

Various kinds of mummery were practiced in ceremonial rites of Moksha and Erzya - they wore masks and fancy costumes and used utilitarian objects, etc. Putting a mask or a costume on, a person transformed into his character - an animal or any other creature of the beyond. In this regard, the person changed his behavior; he often went beyond the accepted norms. Mummers could start brawling and talking smut, they felt freely to behave with girls and women. Later the custom of mummery lost its magical sense and became a way of entertainment, especially for young people and children. It creates a festive mood for all participants of the rite. 


\subsection{The status of the problem}

Researchers offer various hypotheses for origins of the mummery custom. Thus, representatives of the mythological school of Ya. Grimm, V. Mannkhard, M. Müller considered that masks (mainly the masks of animals) are ceremonial elements, an embodiment of the "heavenly" animals: thunderclouds, sun and planets (J.Grimm, 1835; W. Mannhardt, 1866-1867; M. Müller, 1856). Nowadays this point of view is considered as archaic and practically none of modern scientists share it. Ritual masks were considered also as remnants of totemic ceremonies or an embodiment of ancestral spirits; some scientists believe that they also had certain magic functions. In particular, they arrogated the ability to increase the fertility to images of highly productive animals such as a goat, a bull, a horse. This custom is interpreted also as the remains of the secret unions (generally male ones), which are still instant for some peoples of Africa, Oceania, South America. Thus the main reason why the masks were used was to intimidate women and children. It should be noticed that this custom of intimidation of children existed also in ceremonial culture of the Mordovians. Elderly respondents say that mothers in order to calm down their naughty children, used to tell them: "Don't be naughty or mummers will come!" Children were really afraid of the mummers and were hiding out from them (Kornishina, 2011).

\section{Methods of Research}

Theoretical basis of the present research is a comparative method which gives the opportunity to provide a stage-bystage historical research of the ceremonial complex, to understand how innovations appear, to define a basis and initial value of its structural components, their interaction and trends of development. Though this method can not always apply for the absolute accuracy and reliability as it always includes a hypothesis and a subjective sentiment but in a certain degree it can be justified by a motivation to recreate a complete picture of the Mordovian traditional and ceremonial culture. This method allows us to compare the studies of ceremonial elements of the Mordovians and other peoples of the Ural-Volga region. The comparative method has been supplemented with filed methods. Field researches were conducted by the authors in the Moksha and Erzya villages of Orenburg, Penza, Samara regions and the Republic of Mordovia. During the field work the authors also used the methods of direct supervision and interviewing.

\section{Results and Discussion}

\subsection{Types of masks in ceremonial culture of the Mordovians}

There are different types of masks spread among the Mordovians. Quite often so-called "frightening" masks were used during the Christmas-tide. Usually they used bast, paper and carton to make horns or a big nose, those masks were called "chamaks". Sometimes people painted the masks in a black color or simply smeared their faces with soot. The pumpkin was also used as a material for the "frightening" masks. They hollowed a pumpkin out and cut the slits for eyes and a mouth. Then they could put the pumpkin upon their head or just carried it in hands. In that case they lighted a candle inside the pumpkin.

According to many researchers these masks were a personification of the spirits of the dead. That is why they appeared in the ceremonies which were carried out at the beginning of a new year. As the matter fact according to national believes the wellbeing of people in a coming year depended on the favor of their ancestors. From this point of view S.A. Tokarev explained the reason why masks and faces were colored black. He considered that this color symbolizes death, the beyond world, and the custom of coloring faces black was the easiest way to represent people as their ancestors (Tokarev, 1983). Some scientists believe that the frightening masks helped the people wearing them to draw together with otherworldly forces which were gaining strength in New Year's Eve. "Drawing together" with them a person tried to protect himself from their bad influence.

Animal masks, especially horse and bear masks were widespread among the Mordovians that was connected with their totemic views (their belief in the supernatural relationship existed between a certain group of people and species of animals, plants, etc.). The similar connection can be observed, for example between a person and a bear who was traditionally considered as symbol of good. According to national beliefs the bear is a helper and a guardian for people because it is their relative, their congener. Bears are mentioned in many songs, legends and fairy tales of the Mordovians. That is why bear skulls were often utilized as a talisman to protect from the "evil spirit": they were kept in household areas, stables, apiaries, etc. Those who didn't have bear skulls, had to bring a live bear to their yards and pay money to the bears' owners. If a bear took a firm stand and didn't want to enter someone's yard, they believed that the evil spirits were inside. 


\subsection{The images of a bear and a horse}

Bears were widely honored by other peoples. So, the Mari, the Khanty, the Mansi associated the bear as a symbol with successful hunting, fertility of soil and large family. The Udmurts called him "an old man" and considered that the bear was able to punish angry people who hurt their relatives. In Karelian folklore the bear was often a protector of a positive character. Russian peasants used bear wool to scare the brownie from their homes.

The image of the bear (an ofta, an ovta) also presented at the Mordovian wedding. Usually it was represented by a woman who was wearing a fur coat and a fur cap which were turned inside out. The "Bear" met a just-married couple at the groom's house, sprinkled them with hop and wished the young wealth, force to the groom and fertility to the bride. This custom remains among the Mordovians up to date though its initial meaning was forgotten. Elderly respondents explained it as follows: "The custom shows that the married life is as difficult as the bear's life". Now such mummery is often a motive for jokes and fun. For example, among the Mordovians of Samara region a woman representing a bear right after a young couple brings water (another wedding tradition), "sits down" on a stick and "goes" to bring water. When guests ask her: "What are you doing?" She answers: "All water of a young wife has been spilled, I will bring more".

Horses were also honored among the Mordovians. They believed that sorcerers and evil forces were afraid of horses. That is why on the Epiphany Day when people were casting the evil out, they arranged horses riding. They believed that by doing it they broke legs of the evil ghosts. Other peoples also associated horses with similar qualities. For example, the Udmurts sacrificed a horse to the god of disease (Chara) in order to throw off illnesses.

\subsection{Costumes of mummers}

Thus, the costumes of mummers were compound. The main characters of this or that ceremonial action, as a rule, put on other elements of clothing along with a certain mask. Except earlier mentioned fur coats, they could also wear old caftans, various hats, etc. For example, a costume of a Pokrov-baba, the woman who was considered as an embodiment of Pokrov holiday, consisted of a face mask, and also a fur coat turned inside out, bast shoes and a beard made of a bunch of hemp. The sweeper or a broom were also obligatory attributes of this character. The ritual cleaning of premises before winter when people started spending the most part of time in their houses was the main function of Pokrov women. When visiting her neighbors the woman (usually elderly) played the role of the Pokrov woman: she was sweeping walls and a ceiling up, as if she was cleaning them of spiders, cockroaches, and wished health and prosperity to hosts. The hosts rewarded the Pokrov woman and usually gave her pies, pancakes, etc.

While the Pokrov woman and most of Christmas characters had masks and special costumes, people representing Spring and Easter simply put on festive clothes without any elements of mummery. Though sometimes their costumes had details distinguishing them from other participants of ceremonies, for example a big wreath of Spring. In some places people chose a girl (of $7-10$ years) as a personification of Spring and her clothes were decorated with shawls. Costumes of youth groups' leaders (such as andyamo, atamanka, pokshket, pryavt) also had distinctive elements. So, the head of a youth group which went around the houses that was a tradition on the second day of Easter, carried a special hat made of straw in the form of a yurta with about height of an arshin. The head of a maiden holiday of Piwan kudo in the Kochkurovsky district of Mordovia, unlike the other participants, didn't wear a maiden frontlet, but a hat of a married woman.

Sometimes the main holiday characters wore items of traditional clothing which are not used now. For example, leaders of a maiden holiday wore ancient shirts "pokay" when they had already become a rarity. Sometimes the ancient clothes were brought simply ahead of ceremonial processions. In the beginning of the XX century the Mordvinian girls of Stavropolskiy and Bugulma districts of Samara province carried a pokay with themselves during processions around houses for Easter. Before the Trinity when girls took part in processions, little girls were going first and had a decorated necklace, a karkstama (waist decoration) and their leader's "pryavt teyper" (lit. main girl decoration) in their hands. It was decorated with wool, beadwork, coins and squirrel tails.

Often straw of cereals and grain crops were used as a part of a costume, as it was the ancient symbol of fertility among many peoples. Mummers were wearing straw belts, filled their clothes with straw, made straw capes and hats. For example, a man pretending to be a sow in the Christmas game "exile of pigs" filled his caftan with straw.

Various greens which represented a spirit of vegetation were one of basic elements of clothes of people, who took part in spring and summer ritual ceremonies. Such ceremonial characters as Spuzhalat and Kalinat sewed grass and a branch on their heads and fern leaves to their costumes. Vir lomat' (forest people) and Viryavat (forest women) were entangled by vegetation from feet to the head. These characters often scattered flowers and branches of trees on a grain field to increase its fertility. 
Decorating costumes of ceremonial characters with branches, herbs and flowers, occurred among different European nations. On the Balkans, for example, the custom of calling for a rain was widespread. During the ceremony a girl who was wrapped up in greens (the peperuda or dodola) was poured over with water. Images of so-called "wild" people wrapped up in flowers and branches are known among the Germans and the Austrians. They presented at all holidays and represented the dying and reviving vegetation deities (they were caught in the woods, "killed" and then they "revived").

\subsection{Travestism and ritual nakedness}

During various holidays and ceremonies among the Mordovians such type of mummery as travestizm was also observed. For example, among the Mordovians of Samara region the leaders of a maiden holiday called atamanka, wore men's caps, long black caftans with red veils attached to their shoulders. This custom is common among many peoples. Researchers put forward some explanations of this custom. One group of them considers that people put on clothes of the opposite sex "to mask", to change their faces. According to the others (for example, G. Bauman) - the practice of travestizm is generated by spontaneous aspiration of people to raise their sexual potentiality through which they can influence on fertility of fields and cattle (Baumann, 1955). Detailed manifestation of travestizm can be observed with an example of one of the maiden holiday ceremonies. On one of its stages two girls who were dressed up as guys ("Cossacks") were sent to pasture village cattle. "Cossacks" wished the cattle and the soil fertility and health.

Travestizm was also observed during processions of Christmas-tide. The ceremonial procession was headed by masks of Roshtuva babat (Christmas old women), their roles were played by a guy and a girl. The guy put on a women's shirt, women's whist ornament - pulay and Kokoschka on his head and the girl dressed up as a guy. Girls, the leaders (andyamo) were also wearing male clothing during a celebration of the Trinity in the Erzyas' Pavlushkino village of the Samara province. This custom was also observed in the village of Orkino of the Saratov province. Ceremonial change of sex was also peculiar for such characters as the Bride, the Groom, Ded (Grandfather), Babka (Grandmother), the Shepherd, etc. Carriers of these masks played various comic sketches. For example, during the spring farewell ceremony Ded and Babka played a quarrel, imitated labor processes: the grandfather was "spinning" bast shoes, the Grandma was "embroidering". Nowadays travestizm elements may also be found in a wedding mummery. So, in a group of the bride's relatives who go to the house of the groom to look for "yarka" on the second day of wedding, women wore men's clothing and men wore female clothing.

Ceremonial nakedness was also practiced among the Mordovians. So, while sowing flax sowers didn't put trousers on. They asked Paksya ava (a field deity) to make more flax "for trousers". When sowing hemp sowers were in ragged shirts asking their gods to provide a good harvest of this culture "for new shirts". In these cases nakedness had, probably, the producing value: the idea of soil fertility was connected with human fertility, thier reproducing abilities.

It is possible that the same reason was the basis of the custom described by P. I. Melnikov. The main point of that custom was that married women or girls during collecting food from public prayers had to be semi-naked. Here is an example how the preparations for rural prayer Vel ozkz took place. When collectors entered a house, "married women of a family stood in front of them, turning their backs to a door. Their shoulders and breasts were naked ... the senior married woman took for tapes a bag with flour, showered it through the head back on her naked shoulders and without looking back ... moved back to the door. When she came to collectors, parindyait (one of the heads of the procession) put sacred parka to her back, and yanbed took a bag with his one hand and slightly pricked the woman's naked shoulders and back with the other hand. After that he cut the tapes off and the bag fell in parka, but the ends of tapes remained in women's hands. She went back to a table, without looking back. Then another girl went to the collectors in the same way with the other bag, then the third with the third bag, etc. If there was only one married woman in a family, she carried all prepared bags one by one in a way described above." (Mel'nikov, 1981).

Ritual nakedness was also used in the apotropaian ceremonies which were held to protect crops, people, cattle from any misfortune or illness. For example, in order to preserve their health and as treatment from infertility and other illnesses, naked women ran on a dewy grass on the Whit Monday. During Tasta ozks (exiles of a locust), two or three young girls representing "locust" were to hide naked in crops. The participants of a ceremony of plowing around (per'f keryam, pir' keryamo) hold on during locust epidemics were also naked. By the end of the XIX century the custom of nakedness, in this case, was replaced by a custom of wearing shirts only, without any belts and being barefooted. The similar phenomenon is also observed in divination ceremonies. From the end of XIX to the beginning of the XX century women and girls usually went to tell fortune in their underwear shirts and also without any belts with flowing hair. But probably by analogy with other European people, naked divination traditions were more archaic. Thus, ritual nakedness consisted of two elements: it protected from otherworldly forces, and on the other hand, it helped to draw together with 
them to foresee the future.

There are almost no special publications devoted to studying a place and a role of masks and mummery in ceremonial culture of the Mordovians. This issue was briefly studied by researchers during the studies of certain rites. Thus, the Finnish scholar U. Harva describes this custom as an element of the marriage ceremony (Harva, 1952). Art critics and specialists in folklore consider them in the context of theatrical and musical forms of ceremonial culture, showing their development from theatre elements in various ritual actions till modern displays of folk art. However, none of them considered mummery as an element of traditional and ceremonial culture of the Mordovians which is one of the most important blocks in a system of ethnos, and which is considered in this article.

\section{Conclusion}

In conclusion we would like to notice that masks and mumery are only a one part of ritual traditions of the Mordovians. There are also a variety of other components which also played and still play an important role in their ceremonial culture. The majority of them, having arisen in the ancient time, remained in the Mordovians' life up to the beginning of the XX century, and some of them (though in a transformed way) remained up to date. They represent a set of the relic phenomena which bear religious, social and economic representations of the previous eras. These elements are repeated in various combinations, creating variety of ceremonies and holidays within one ethnos. The main ceremonial components of the ethnos belonging to the same economic and cultural type, or living in equal geographical conditions are often similar, as using of masks and mummery described above. Though, they may be perceived in different context by representatives of various nations. All these aspects create new opportunities for research, prospects for further studying.

\section{Acknowledgments}

The work is performed according to the Russian Government Program of Competitive Growth of Kazan Federal University.

\section{References}

Baumann H. (1955). Das doppelte Geschlecht. Berlin.

Grimm J. (1835). Deutsche Mythologie. Gottingen.

Harva U. (1952). Die Religiosen Vorstellungen der Mordwinen. Helsinki.

Kornishina G.A. (2011). Tradicionno-obrjadovaja kul'tura v sisteme mordovskogo jetnosa. Lap Lambert Academic Hublishing GmbH \& Co. KG. Germany.

Mannhardt W. (1886-1887). Wald- und Feldkulte. Berlin.

Mel'nikov P.I. (Andrej Pecherskij) (1981). Ocherki mordvy. Saransk: Mordovskoe kn. izd-vo.

Müller, F.M. (1856). Comparative Mythology. London: G. Routledge and Sons.

Tokarev S.A. (1983). Maski i rjazhenie. Kalendarnye obychai i obrjady v stranah Zarubezhnoj Evropy. In S.A Tokarev (Eds.) Istoricheskie korni i razvitie obychaev. M.: Nauka, 185-193. 